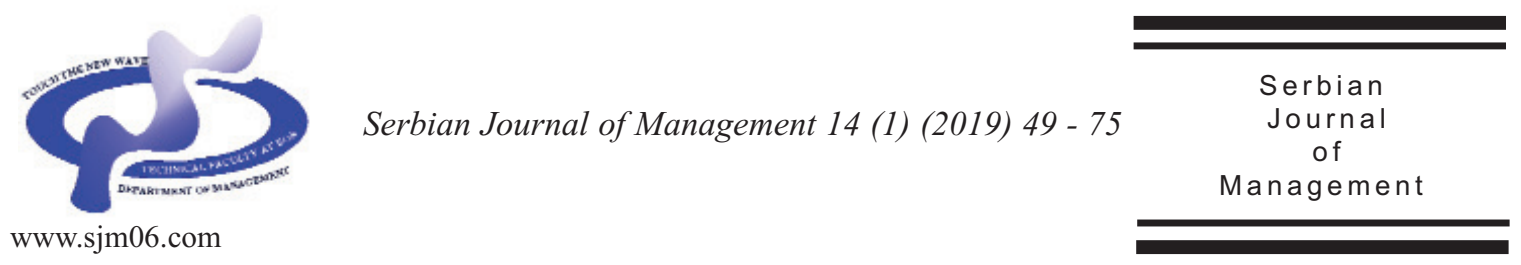

\title{
A HYBRID MODEL OF FACTORS AFFECTING ADOPTION OF MOBILE BANKING TECHNOLOGY BETWEEN CUSTOMERS OF IRANIAN BANKS
}

\author{
Bagher Asgarnezhad Nouri ${ }^{a *}$ and Milad Soltani ${ }^{b}$ \\ $a_{\text {University of Mohaghegh Ardabili, Faculty of Literature and Humanities, }}$ \\ Department of Business Administration, Daneshgah Street, \\ 56199-11367, Ardabil, Islamic Republic of Iran

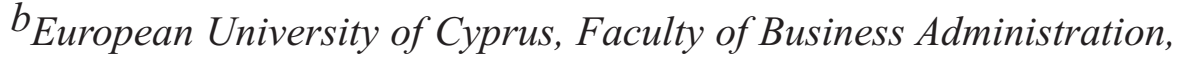 \\ Diogenis Street 6, 2404 Engomi, 1516 Nicosia-Cyprus
}

(Received 3 November 2017; accepted 16 May 2018)

\begin{abstract}
This study aims at providing a hybrid model of mobile banking adoption in the banking industry of Iran. Based on reviewing the models of technology adoption, the main effective factors were divided into four general categories including personal, social, organizational and technological factors. The population of the study consisted of the customers of public banks. With regard to the infinity of the population, based on Morgan table, 384 customers were selected as the sample of the study. A standard questionnaire was used to collect the required data for all the research variables. The research hypotheses were tested using structural equation modeling and based on AMOS software. The results show that some personal, social, organizational and technological factors have a positive significant effect on perceived usefulness and perceived ease of use of mobile banking. Perceived usefulness and perceived ease of use have a positive significant effect on the attitude towards mobile banking. In addition, the positive significant effect of attitude towards the use of mobile banking on the tendency to use mobile banking and vice versa was confirmed.
\end{abstract}

Keywords: mobile banking, technology adoption Models, individual factors, social factors, technological factors, organizational factors, perceived usefulness, perceived ease of use

1. INTRODUCTION customers are forced to use such

Today, technical advances have occurred services requires using new technologies. in different areas and companies and their Accordingly, there have been considerable

* Corresponding author: asgarnezhad.research@gmail.com

DOI: $10.5937 /$ sjm14-13429 
technical advances in the banking sector and each customer, through virtual technology, can do his/her banking operations easily and in the shortest possible time. Electronic banking is among the new banking technologies which offer many services to the customers without their physical presence in the bank (Bastic, 2012). Ebanking has led to offering quick, complete, accurate and desirable services to customers around the world while the slowness of traditional systems deprives the banks of golden opportunities to attract more customers (Schneider, 2006). Experts define e-banking as the use of Internet by banks to provide their customers with banking services, and the use of Internet by customers to organize, control, and carry out transactions on their bank accounts (Moghadasi, 2010). However, some experts have proposed a more general definition and believe that the use of other tools and electronic channels such as mobile, phone, and digital TVs to inform, communicate and carry out banking transactions can be included under the definition of electronic banking (Gholipour Soleimani \& Imani, 2010).

In e-banking, different tools such as electronic money, electronic check, electronic wallet, different kinds of cards such as debit cards, credit cards, charge cards, ATM machine and POS system are used (Schneider, 2006). But in recent years, developments related to the field of telecommunications have led to the extended use of mobile phones around the world. Accordingly, mobile banking, as another new tool of e-banking, has been provided to customers to facilitate the provision of services to them (Lee \& Chung, 2009). Today, the provision of banking and financial services through using mobile phones is one of the modern methods in providing banking services. Mobile banking, as a wireless communication channel, has been provided in the banking transactions for creating value by the customers (Titova \& Girard, 2014). The use of mobile banking facilitates customers' secure access to banking services without their physical presence, the use of Internet to provide banking services and operations and change different accounts of the customers, and the direct provision of new and traditional banking services and operations to customers through electronic communication channels (Gholipour Soleimani \& Imani, 2010).

Researchers have shown that when the use of a technology is delayed, then, per capita income, skills development, and productivity of the labor will be affected negatively (Anderson, 2010). Since the number of mobile phones is much higher than personal computers, among other means of electronic banking, mobile banking is very welcomed around the world (Laukkanen, 2007). However, Tanner (2008) found out that only $4 \%$ of 25 million users of the US banking services use mobile banking actively. Another study shows that only $12 \%$ of German users use their mobile phones to buy something or do their banking transactions (Tanner, 2008). In Iran, despite intense efforts in the area of e-banking establishment during the last decades, it seems that these services are not welcomed by customers adequately (Fatemi-eArdekani, 2005). Therefore, given the lack of interest in using this technology of electronic banking, it is necessary to identify the factors influencing the use of mobile banking in order to improve the use of electronic banking system, especially mobile banking.

Several factors affect the adoption of new technologies and, hence, the use of mobile 
banking. The most important technology adoption model was proposed by Davis in 1986. According to this model, five main variables of technology adoption model include perceived usefulness, perceived ease of use, attitude, intention, and behavior. For example, researchers found out that there is a direct relationship between perceived usefulness and attitude towards usage (Hung et al., 2006; Salehi \& Rezaei-moghadam, 2009). In addition to the Davis model (1986), Ragers (1995) showed that innovation features such as compatibility, relative advantage, complexity, testability and visibility can contribute to the adoption and application of innovation. Moreover, Venkatesh and Davis (2000), using technology adoption model as the initial model, added some new theoretical constructs such as social effects (social norms) and processes of cognitive tools (employment relationship, output quality, provability of the results, and ease of use) to the model. They also believe that organizational factors such as availability of support, security and privacy, and the features of the system and web can affect technology adoption (Bandura, 2001). Other researchers believe that demographic factors such as gender, age, income and educational levels can influence technology adoption (Saleh-ahmadi, 2011). According to what was said, each of the traditional and new presented models in the area of technology adoption has introduced different factors. Since it is difficult to take into account all the factors in the field of using mobile banking services, using several known theories proposed in this area and observations on psychological, demographic and personal characteristics of mobile banking users and technical features of these services, there was an attempt in this study to develop the conceptual model of the study through combining the models proposed in previous researches. According to various researches conducted in this field and modeling other studies in the area of mobile banking, particularly multiple models of technology adoption, and based on interviews with professors and banking experts, this model has been designed as a native and comprehensive model to identify factors affecting the use of mobile banking services in the banking industry of Iran. According to literature review, the factors affecting mobile banking technology can be considered in four general categories: 1) personal factors; 2) social factors; 3) technological factors; and 4) organizational factors. Personal factors include previous experience and knowledge of technology; social factors include subjective norms regarding technology, trust in technology and the need for interaction; organizational factors include the availability of support, security and privacy, and the features of the system and web and, finally, technological factors include perceived risk, perceived cost, perceived reliability, service quality and accessibility (Davis et al, 1992; Rezaei et al., 2012; Maleki \& Akbari, 2010; Piralidehi et al., 2013).

Therefore, this research proposes a hybrid model for technology adoption of mobile banking. Hence, through using Davis model as the basis and reviewing other models in the area of the adoption of new technologies, this research intends to investigate the impact of personal, social, organizational, and technological factors on the adoption of mobile banking technology. To this end, the factors affecting the adoption of mobile banking technology will be explained in the theoretical bases section. Then, empirical literature of the research will be reviewed. 
Research methodology will be discussed in the next section and, finally, after analysis of data, conclusions and recommendations will be presented.

\section{LITERATURE REVIEW}

\subsection{Mobile Banking Technology in Iran}

Mobile banking is another tool developed recently in the field of electronic banking. This approach is actually the developed form of Internet and home banking (Hassanzadeh \& Pourfard, 2003). In fact, financial services became possible in the digital world since the advent of wireless Internet and Internet banking concept has been expanded into the mobile world. Mobile banking is a new method to access banking services via a channel based on which customer uses a mobile device and interacts with the bank and is able to have access to banks, accounts, and many other financial services. Using mobile banking, one can do many banking operations such as checking account balance, stop the payment of checks, transfer money from one account to another, and so forth (Hassan-zadeh, 2003). Mobile banking services first were provided through SMS (SMS-based banking), but today mobile banking can be implemented via SMS, installable applications, mobile web browsers and unstructured supplementary services data (Karkhaneh \& Mohammadi, 2012). In general, mobile banking services, in terms of the communication type, can be divided into four groups of notifications and alerts (in order to inform the customer of the transaction performed or should be performed), information (information about transactions and account balance in certain times), requests (send a request by customer about an specific transaction or account), and money transfer (transfer funds between a customer's accounts or paying a third party) (Vafaei, 2010).

Currently, mobile communication network and mobile technologies are increasingly and widely used by the public which can provide the ground for using mobile banking services. According to available statistics, the diffusion of mobile devices is higher than any other technology (Vafaei, 2010, p. 32). Today, many banks around the world provide their customers with mobile banking services. The main motivation of the Banks for providing mobile banking services is to have effective distribution channel and reduce operating costs (Sarfarazi, 2009). In Iran also many public and private banks have started to offer mobile banking services and now customers can have access to these services through various banks (Vafaei, 2010).

\subsection{Determinants of Mobile Banking Technology Adoption}

Given the fact that it is so difficult to take into account all the factors in the field of using mobile banking services, using several well-known theories proposed in this area and observing psychological, demographic and personal characteristics of the users of mobile banking services and technical characteristics of these services, the conceptual model of the research has been obtained which is a combination of the models offered in previous researches. According to various researches conducted in this field and modeling other studies in the area of mobile banking, particularly multiple models of technology adoption and based on interviews with professors and banking experts, this model has been designed as a native and comprehensive model to identify 
factors affecting the use of mobile banking services in the banking industry of Iran. Based on literature review, the factors affecting mobile banking technology can be divided into four general categories: 1) personal factors; 2) social factors; 3) technological factors; and 4) organizational factors (Davis et al, 1992; Rezaei et al., 2012; Maleki \& Akbari, 2010; Piralidehi et al., 2013).

\subsubsection{Personal factors}

One cannot easily overlook the importance of the relationship between demographic variables and technology. If organizations are going to succeed in gaining and maintaining competitive advantages, they have to consider demographic variables as they are. Several studies have found that demographic variables affect technology adoption. Selwyn et al. (2003), for instance, concluded that the rate of computer use varies by gender and age. Likewise, Donnelly (2004) found out that there is a positive relationship between e-commerce adoption and demographic features of the age and gender. While many studies consider such demographic variables as mediating and intervening variables, there are still a few studies which consider these variables as predictive factors in technology adoption model. Dickerson (2003) found that women do not trust the websites, interpret the information taken from the websites, and use Internet to search information professionally and non-professionally. On the other hand, men adopt technical approaches, use Internet as a power and information source, use Internet more than women, and look for financial information. There is a general feeling that older people often have negative feelings towards computer and various studies have confirmed it. Matilla et al (2003), for example, found that older people are not generally among the first to adopt the technology. These studies showed that younger people, more than older ones, have a relationship and collaboration with technology. Knight and Pearson (2005) found out that age and sex cannot predict employees' use of computers. These researchers found that age and sex have no negative effect on computer use. The impact of the users' education level on the use of new technology has been proven in various studies (Elahi et al., 2010).

\subsubsection{Social factors}

In this study, social factors include confidence/trust in the technology, the need for interaction and subjective norms regarding technology which will be explained in continue:

1.Perceived trust: Many studies in the area of distribution channel communication define trust as the level of belief a partner has in the honesty and benevolence of his/her business partners and other issues related to this concept (Taghavi-fard et al., 2012). Risk and perceived trust are contiguous concepts which have been frequently diagnosed as the key barriers to the adoption of e-banking services. Kim et al. (2009) proved that when mobile banking is perceived more risky than normal banking, the person's initial trust in the services is considered as a factor necessary for the use of mobile banking. Koenig et al. (2010) concluded in their study that there is no direct relationship between trust and the intention to use mobile banking; on the contrary, this factor, through compatibility and perceived risk directly influences the intention to use mobile banking (Behboudi et al., 2013). 
2. The need for interaction: Need for interaction is appropriate to create and maintain a personal relationship during the time when a user uses personal services. Those who use mobile banking services, are normally business customers who make their payments through this technology and remain business customers till they are doing their banking operations. At this interval, there appears an interaction between the customers of mobile banking and its providers and this kind of interaction increases the amount of adoption of mobile banking services by the customers. Wessels and Drennan (2010) evaluated the effect of need for interaction on the intention to use and found that there is a negative relationship between interaction and intention to use. In this research, the need for interaction is defined as the customer's faceto-face give and take with a bank's employee and this question arises that to do banking operations and have confidence, if people need to have face-to-face interaction with the bank employees or mobile banking have filled this gap. Therefore, those who have a greater need to have face-to-face interaction will use mobile banking services less (Taghavi-fard et al., 2012).

3. Subjective norms: refer to the social pressure perceived by the person to do or not to do the target behavior. People often do and act based on their perception of what others (friends, family, colleagues, etc.) think, and their intention to accept a behavior is potentially influenced by people with whom they have a close relationship (Mathieson, 1991).

\subsubsection{Organizational factors}

Organizational factors refer to the features by which the provider of mobile banking technology, through adopting policies and programs, tries to encourage customers to use this technology more and more. Among the components of organizational factors mention may be made of the availability of support, security and privacy, the system and web features, and the availability of infrastructure and services.

1. Security and privacy: The biggest challenge in the adoption of information technology is the security-related issues. Confidence in the security and reliability of communication and information technology is an essential issue. On the other hand, if the privacy of people is violated, it will influence the trust of citizens negatively. The risk perceived by customers regarding the use of mobile banking or, rather, the amount of loss or profit they realize, is one of the factors affecting the adoption of mobile banking (Elahi et al., 2012).

2. The availability of support: Considering support mechanisms and supportability of the systems is another determining important factor in the adoption of mobile banking. These mechanisms come to the help of customers in the absence of awareness of the used technology or in case of unforeseen events (Hung et al., 2006).

3. Features of the system and web: Features of the used systems and the information contained in them are among the factors affecting the adoption of information technology. Effective communication, site design and its content are among the key factors determining the perceived quality of e-services. A number of sites because of the lack of appropriate customization and support of the users are not used fully. The lack of applicable procedures and programs which can be used by citizens is considered as one of the weaknesses of the mobile banking technology development. 
4. Availability of infrastructure and availability of services: The establishment and development of electronic systems requires the availability of infrastructure. Governments face the lack of necessary infrastructure as a major obstacle to electronic services. On the other hand, the availability of services has been considered as a factor which influences the adoption of technology (Homner \& Al-ghahtani, 2009). In this regard, access to computer and Internet networks is very significant. The availability of services stimulates the users and makes them use technology.

In addition to the four mentioned factors, there are some other indicators which have been obtained from other models as mediator variables and influence the process of the adoption of mobile banking technology; among these factors mention may be made of perceived usefulness, perceived ease of use and intention to use. These components have been mentioned in many models of mobile banking technology adoption and will be explained in continue.

\subsubsection{Technology factors}

Technology factors have been considered based on the model of duty-technology fitness in this model. Technologies are tools which are used by individuals in performing their duties. Technology features refer to the features which can be used to perform the customers' duties. Mobile banking, compared with other banking methods such as Internet and traditional banking, leads to more fitness of duty-technology for mobile users who are constantly commuting (Zhou et al., 2010). Among the components of technology factors mention may be made of perceived risk, perceived cost, perceived credit, and the quality and availability of services.

1. Perceived risk: Some research conducted on the adoption of new technologies such as mobile banking have shown that perceived risk of a technology plays an integral role in adopting it. Risk has even a much higher importance in the use of mobile banking services, because the mobility of mobile banking services increases its security threat. Because of the telecommunication property of mobile banking services, the use of mobile banking is more risky than fixed devices. Lovelock et al. (2001) reported that the likelihood for adoption of and satisfaction with received services is high when the risk of using them is low. Wu et al. (2007) concluded that there is a significant relationship between perceived risk and the intention to use mobile banking services. Wessels and Drennan (2010) evaluated the effect of risk factor on the attitude towards the use of mobile banking services. They concluded that this variable has a significant negative impact on the attitude towards and finally the use of mobile banking service (Behboudi et al, 2013).

2. Perceived cost: The cost of acquisition and use of new technologies is one of the obstacles to the adoption of these technologies. Additionally, to determine the actual costs and measure the costs of acquisition and the use of new technologies, selectors face with a range of a relatively hidden transaction costs which probably influence the adoption of mobile banking. Previous studies have concluded that the perceived costs can be a major obstacle to the adoption of mobile banking. Wu et al. (2007) found out that costs have a significant negative impact on behavioral intention to use mobile banking. Wessels and Drennan 
(2010) concluded in their research that there is a negative relationship between perceived costs and the intention to use mobile banking services (Das \& Teng, 2001).

3. Perceived credit: Credit is another factor influencing the adoption of IT services. Credit is defined as the reliability of a system and the ability for doing transfers and transactions (Erdem \& Swat, 2004). Koeing Louise et al. (2010) concluded that credit has a significant negative effect on risk and, finally, an indirect effect on the intention to use mobile banking. Wang et al. (2008) concluded that there is a significant positive relationship between perceived credit and the use of mobile banking services.

\subsection{Perceived Usefulness and Perceived Ease of Use}

According to Davis et al (1992) perceived usefulness is defined as the subjective probability of using a technology which can enhance individual performance. Perceived usefulness is known as a key factor which has a significant positive relationship with the attitude towards mobile banking and the intention to use it. For example, perceived usefulness affects positively the adoption of Internet services via mobile phones (Chiu et al., 2005). According to Vanktash and Davis (2000), perceived usefulness is not only important in the adoption of the system information and its calculation, but also is effective in trade and business through mobile phone technology. In technology adoption model, perceived usefulness means that using a special system to what extent increases one's performance (Behboudi et al, 2013). According to Tan and Teo (2000), perceived usefulness has been recognized as an important factor in determining the adoption of a new technology. Likewise, according to Battacherjee (2002), users use a special system to perform their transactions when they have already understood the use of it or it is perceivable for them. KoeingLewis et al. (2010) evaluated the effect of perceived usefulness on the intention to use mobile banking and concluded that there is a positive relationship between this variable and the intention to use. Karahanna and Agarwal (2000) showed that perceived usefulness and ease of use influence behavioral intention both directly and indirectly. Szajna (1996) demonstrated that perceived usefulness directly affects the intention to use, while ease of use affects the intention to use indirectly and through perceived usefulness. Chen et al. (2004) reached a similar conclusion and claimed that perceived usefulness, as an infrastructure, has a direct effect on the intention of use. Therefore, it can be said that perceived usefulness is an effective factor in the adoption of mobile banking technology (Behboudi et al., 2013).

Perceived ease of use refers to the user's tendency of use in which the user expects to make no effort in using the intended system (Davis et al., 1989). Vast and extensive researches have been done about the effects of perceived ease of use on the adoption of mobile banking technology and attitude towards it. Moreover, in many studies, researchers have claimed that both perceived usefulness and perceived ease of use not only are considered important factors in the adoption of a technology, but also affect the long-term use of that technology. In early researches, perceived ease of use investigates the behavior of users through perceived use either directly or indirectly. According to some studies, perceived ease of use is related to the success and quality of the 
information system and customer's satisfaction as well. Ease of use is typically concerned with intrinsic features of information technology (Ramayah \& Lo, 2007). Evidences suggest that there is a positive relationship between perceived ease of use, attitude towards, and intention to use mobile banking technology. Hence, perceived ease of use has a significant positive effect on attitude towards and, finally, on the intention to use mobile banking technology (Wessels \& Drennan, 2010).

\section{RESEARCH BACKGROUND}

Kim et al. (2009) investigated the effect of initial trust on the adoption of mobile banking technology by customers. According to them the indicators of initial trust include relative advantages, structural warranty, brand reputation and the individual's willingness to trust. The results showed that perceived trust has had a positive effect on the adoption of mobile banking technology. Amin Hanudinet al. (2006), using technology adoption method, conducted a research to identify the factors which affect the decisions of bank customers in using mobile banking technology. The variables used in this research include perceived reliability, perceived ease of use, perceived self-efficacy and social pressure. Statistical sample of this study consisted of the banking customers in Malaysia who owned a mobile phone but did not use mobile banking yet. According to the results, social pressure had very little impact on the decision to use, while ease of use had a significant effect on this decision. In addition, a direct relationship was observed between self-efficacy and the intention to use mobile banking and it was found that the credit provided by mobile banking can have a positive impact on the intention to use mobile banking technology. Using DeLoneMcLean Model (model for the success of information systems), Lee and Chung (2009) investigated the factors affecting the users' trust in and satisfaction with mobile banking technology. Riquelme and Rios (2010) examined the effect of gender on the adoption of mobile banking. In their model, they considered the factors of risk, ease of use, usefulness, relative advantage and social norm and showed that risk, usefulness and social norm have the greatest impact on the adoption of mobile banking; they also showed that ease of use in women and relative advantage in men have the most impact on the adoption of mobile banking. Social norm also was more effective in women than in men. Wessels and Drennan (2010) examined the factors affecting the adoption of mobile banking. In this model, the factors of ease of use, usefulness, cost, risk, compatibility with lifestyle, and the need to interact with employees were recognized to be effective in the adoption of mobile banking technology. Taghavifard and Torabi (2010) identified and ranked factors affecting the use of mobile banking services by customers. According to the results, among the features of mobile banking technology, the variables of compatibility/adaptability, cost of use, testability and usefulness were the most effective ones respectively. One the contrary, complexity and perceived risk had little effect. Likewise, among psychological characteristics, risk and thinking about change were effective variables respectively, while opinion leadership had no effect. Rezaei et al. (2012) examined e-shopping intention based on the expansion of adoption 
technology model. The findings indicated that security, ease of use, adaptability and usefulness are significant predictors of attitude towards e-shopping intention, and normative beliefs have positive effect on eshopping intention. Kim et al. (2010) proposed a model about the factors influencing the adoption of payments through mobile phone. The results showed that ease of use and usefulness are the two main causes of adoption; compatibility was not the main reason almost for all respondents, and there was a relationship between the people's feeling towards ease of use and their knowledge about payments through mobile banking. Moreover, personal innovation has had an impact on the observed ease of use. Ashtiani and Asadi (2011) examined the factors affecting the adoption of mobile banking among the customers of Parsian Bank in the city of Arak. In this study, the effect of perceived usefulness and perceived benefits on attitude towards the use of mobile banking was not confirmed. The results showed that perceived ease of use, as one of the defaults of people attitude towards the use of mobile banking, has an effect on the intention to use this new banking service. Ghorban Zadeh et al. (2013), using meta-analysis approach, examined the factors influencing the adoption of information technology in Iran. In this study, using comprehensive metaanalysis (CMA) software for data analysis, 19 studies were selected in connection with the adoption of information technology in Iran and 21 hypotheses and variables were chosen. The results of meta-analysis showed that the variables of employee empowerment, the extent of the use of technology, perceived ease of use and perceived usefulness have the highest impact on the adoption of information technology in
Iranian organizations. According to the research conducted by Wang et al. (2008) in the theoretical framework of Davis technology adoption, they entered a new variable into the initial model which was called sense of confidence; this new variable reveals users' concern regarding security and privacy issues in making decision for the adoption of Internet banking. This study investigated the effect of computer selfreliance on the behavioral intention of users through the variables of applicability, ease of use, and confidence. From the viewpoint of users, the variable of ease of use has had the greatest impact in shaping behavioral intention of customers. After this variable, the variables of sense of confidence and sense of applicability have the next ranks respectively. Konjkav Monfared and Mirhossein (2014) examined the factors influencing the adoption of mobile banking technology by the customers of the Saderat Bank branches in Yazd. The results showed that all the factors identified in the model have direct or indirect effect on users' actual use of mobile banking technology. Accordingly, the variable of perceived benefits was the most effective factor. Riquelme and Rios (2014) examined the effect of gender on the adoption of mobile banking. In their model, they considered the factors of risk, ease of use, usefulness, relative advantage and social norm and showed that risk, usefulness and social norm have the greatest impact on the adoption of mobile banking; they also showed that ease of use in women and relative advantage in men have the most impact on the adoption of mobile banking. Social norm also was more effective in women than in men. 


\section{CONCEPTUAL MODEL AND HYPOTHESES}

Based on the explanations provided in the previous sections, individual factors such as previous experience and knowledge of technology, social factors including subjective norms regarding technology, trust in technology and the need for interaction, organizational factors including the availability of support, security and privacy, and features of the system and Web and, finally, technological factors, including perceived risk, perceived cost, perceived reliability/credit, quality and accessibility of services have been considered in this research. Hence, the aim of this study is to investigate the effect of these factors on perceived usefulness, perceived ease of use, attitude towards the use of technology, and intention to use technology. In this regard, the model of the current research is presented based on the previous studies and the theories and models proposed in the literature review section. Using the model of Davis and combining it with other presented theories and models, the hybrid model of the research is like the figure 1.

Considering the conceptual model, the research hypotheses are as follows:

1. Individual/personal

factors (including previous experience and previous knowledge) have effect on perceived usefulness of mobile banking.

2. Individual/personal factors (including previous experience and previous knowledge) have effect on perceived ease of use of mobile banking.

3. Social factors (including subjective norms regarding technology, trust in technology and the need for interaction) have effect on perceived usefulness of mobile banking.
4. Social factors (including subjective norms regarding technology, trust in technology and the need for interaction) have effect on perceived ease of use of mobile banking.

5. Organizational factors (including the availability of support, security and privacy and the features of the system and web) have effect on perceived usefulness of mobile banking.

6. Organizational factors (including the availability of support, security and privacy and the features of the system and web) have effect on perceived ease of use of mobile banking.

7. Technological factors (including perceived risk, perceived cost, perceived reliability, service quality and accessibility) have effect on perceived usefulness of mobile banking.

8. Technological factors (including perceived risk, perceived cost, perceived reliability, service quality and accessibility) have effect on perceived ease of use of mobile banking.

9. Perceived usefulness has impact on attitude towards the use of mobile banking.

10. Perceived ease of use has impact on attitude towards the use of mobile banking.

11. Attitude towards the use has impact on the intention to use mobile banking.

12. Intention to use has impact on the use of mobile banking.

\section{METHODOLOGY}

The current research, in terms of objective is an applied research and in terms of collecting and analyzing data is a descriptive and correlational one, because it describes the situation of the variables and the relationships among them and, using 


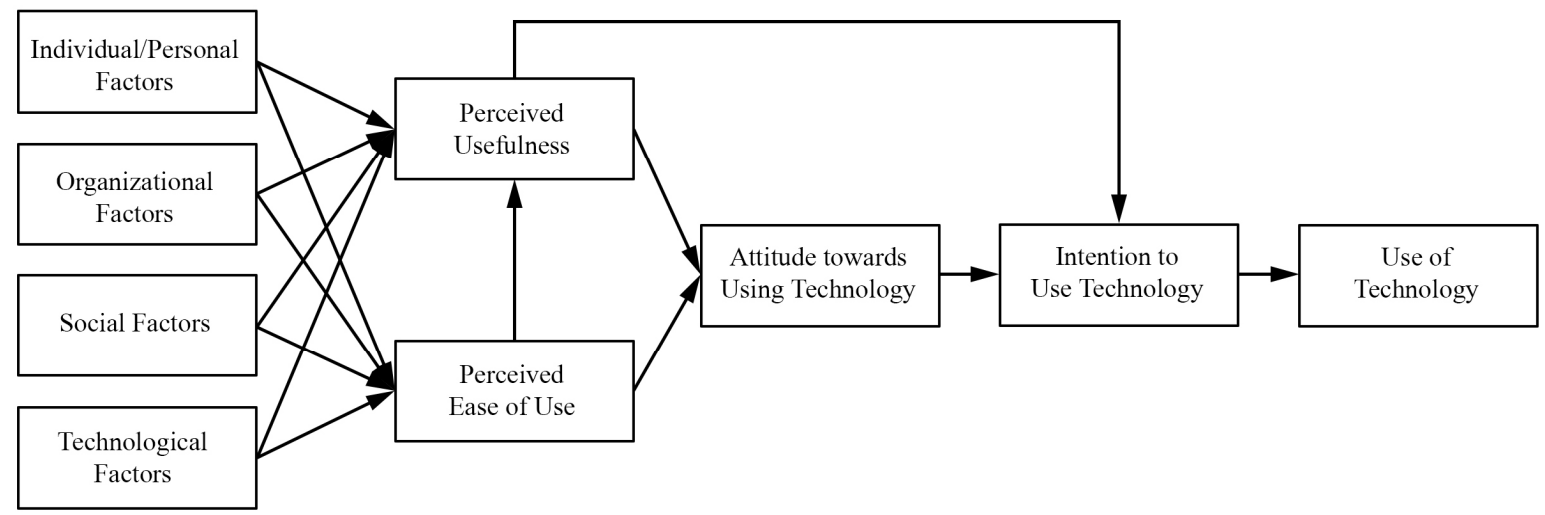

Figure 1. Conceptual model of the research (Davis et al, 1992; Oren \& Dahlberg, 2008; Rezaei et al., 2012; Maleki \& Akbari, 2010; Piralidehi et al., 2013)

statistical analysis techniques, tests and explains the relationship between the variables.

The population of the study consists of the customers of public and private banks in the city of Ardabil who at least once have used mobile banking technology. According to the infinity of the statistical population, with the assumption of infinite population, Cochran formula was used as follows to determine the sample size:

$$
n=\frac{Z \frac{a^{2}}{2} p(1-p)}{\varepsilon^{2}}
$$

In this equation, $\varepsilon$ and $\mathrm{Z} \alpha / 2$ stand respectively for the error sentence and normal distribution at the level of $\alpha$; P and 1-P stand for the possibility of success and failure respectively; and $\mathrm{n}$ is the minimum sample size. Confidence level has been considered $95 \%$ in this research. Given the large population of the study, using the mentioned formula, the sample size was estimated as 384 subjects. Members of the sample were selected through visiting different branches of the intended banks. Table 1 shows the members (banks) of the population and the samples selected from each bank.

Two methods have been used for data collection: library method for the formulation of the literature, and field method for the collection of data from the sample. Data collection tool is a standard questionnaire. The resources used to adjust the questionnaire for each variable are shown in table 2.

The questionnaire validity assessment was performed using face validity method. That is, the questionnaire was given to some faculty members and experts and their views were considered on the validity of the items used to measure each variable. The reliability of the questionnaire was also tested using confirmatory factor analysis the results of which are presented in the research finding section.

Several different methods are also used for data analysis. To this end, first, KolomogrovSmirnov test is used for normal distribution of data. In the case of data normality, the reliability of the questionnaire is assessed using confirmatory factor analysis. Finally, the research hypotheses are tested based on structural equation modeling and path analysis model and using AMOS software. 


\section{RESULTS}

To test the research hypotheses, first, normal distribution of the variables is assessed. In the present research, Kolomogrov-Smirnov test have been used to assess normal distribution of data. Table 3 shows the results of this test.

According to the results of the table 3, significance level is more than 0.05 for all variables indicating that the variables have a normal distribution and parametric statistical methods can be used to test the research hypotheses.

Before testing the original model and the research hypotheses, using factor analysis method, the measurability of the research variables is assessed by the questions of the questionnaire. Table 4 shows the results of the first order confirmatory factor analysis based on the research questionnaire.

The results of the table 4 shows that significance level is smaller than 0.05 in all questions. Thus, it is concluded that the questions of the questionnaire have a good condition and have the ability to measure the research variables. In order to test the research model, path analysis method has been used. Figure 2 shows the results of estimating the relationship between the variables based on path analysis model.

Table 5 shows the results obtained from the test of research hypotheses based on path analysis method.
Based on the results of the table 5, significance level of the impact of personal factors including previous experience and knowledge of technology on perceived usefulness of mobile banking is smaller than 0.05 and their regression coefficient is positive. Therefore, it can be said that previous experience and knowledge of technology can improve perceived usefulness of mobile banking. Hence, the first hypothesis is confirmed. In a similar way, significance level of the impact of individual/personal factors including previous experience and knowledge of technology on perceived ease of use of mobile banking is smaller than 0.05 and their regression coefficient is positive. Therefore, it can be said that previous experience and knowledge of technology can improve perceived ease of use of mobile banking. Hence, the second hypothesis is confirmed too.

Significance level of the impact of social factors including subjective norms regarding technology, trust in technology and need for interaction on perceived usefulness of mobile banking is smaller than 0.05 and their regression coefficient is positive. Thus, it can be said that these factors can lead to the improvement of perceived usefulness. Accordingly, the third hypothesis is confirmed. Moreover, among the social factors, significance level of the impact of

\section{Table 1. Size of Population and Sample}

\begin{tabular}{cccc}
\hline Bank & The sample size & Bank & The sample size \\
\hline Melli & 51 & Maskan & 37 \\
\hline Mellat & 42 & Postbank & 24 \\
\hline Saderat & 32 & Pasargad & 25 \\
\hline Keshavarzi & 28 & Saman & 20 \\
\hline Refah & 32 & Parsian & 18 \\
\hline Sepah & 28 & Sina & 12 \\
\hline Tejarat & 25 & Karafarin & 10 \\
\hline
\end{tabular}


Table 2. Composition of the research questionnaire

\begin{tabular}{ccc} 
Variable & Number of questions & Kesource \\
\hline $\begin{array}{c}\text { Use of technology } \\
\begin{array}{c}\text { Previous experience of using } \\
\text { technology }\end{array}\end{array}$ & 2 & Kamal (2006) \\
\hline $\begin{array}{c}\text { Previous knowledge of technology } \\
\text { Subjective norm towards technology }\end{array}$ & 3 & $\begin{array}{c}\text { Behboudi et al. (2013); Konjkav Monfared \& } \\
\text { Mirhoseini (2014) }\end{array}$ \\
\hline Trust in technology & 3 & $\begin{array}{c}\text { Behboudi et al. (2013); Karkhaneh \& } \\
\text { Mohammadi (2012) }\end{array}$ \\
\hline The need for interaction & 4 & $\begin{array}{c}\text { Behboudi et al. (2013); Konjkav Monfared \& } \\
\text { Mirhoseini (2014) }\end{array}$ \\
\hline The availability of support & 3 & Abdi \& Danaeifar (2010) \\
\hline Security and privacy & 3 & Abdi \& Danaeifar (2010) \\
\hline Features of the system and web & 3 & Teo (2010) \\
\hline Perceived quality & 3 & Bonham et al. (2001); Lee \& Rao (2007) \\
\hline Availability & 2 & Dumner \& Ghazi (2009) \\
\hline Perceived ease of use & 3 & Davis (1989) \\
\hline Perceived risk & 3 & Humner \& Ghazi (2009) \\
\hline Perceived cost & 4 & Davis (1989); Hung et al. (2006) \\
\hline Perceived credit & 3 & Hashemian \& Isaei (2014); Moghadasi (2010) \\
\hline Intention to use technology & 2 & Davis (1989); Hung et al. (2006)
\end{tabular}

Table 3. The results of Kolomogrov-Smirnov test

\begin{tabular}{cccc}
\hline Variable & Mean & Standard deviation & Significance level \\
\hline Use of technology & 2.5526 & 1.04824 & 0.000 \\
\hline Previous experience of using technology & 2.2083 & 0.80106 & 0.000 \\
\hline Previous knowledge of technology & 2.2079 & 0.93142 & 0.000 \\
\hline Subjective norm towards technology & 2.7105 & 0.84784 & 0.000 \\
\hline Trust in technology & 2.6809 & 0.7262 & 0.000 \\
\hline The need for interaction & 2.5702 & 0.56533 & 0.000 \\
\hline The availability of support & 2.5798 & 0.8672 & 0.000 \\
\hline Security and privacy & 2.664 & 0.76973 & 0.000 \\
\hline Features of the system and web & 2.5307 & 0.56055 & 0.000 \\
\hline Perceived quality & 2.3513 & 0.66549 & 0.000 \\
\hline Availability & 2.4298 & 0.63147 & 0.000 \\
\hline Perceived cost & 2.9009 & 0.91878 & 0.000 \\
\hline Perceived quality & 2.4776 & 0.76459 & 0.000 \\
\hline Intention to use technology & 2.2456 & 0.71169 & 0.000 \\
\hline Perceived usefulness & 2.2447 & 0.77262 & 0.000 \\
\hline Perceived ease of use & 2.4798 & 0.8023 & 0.000 \\
\hline Attitude towards using technology & 2.2487 & 0.71314 & 0.000 \\
\hline
\end{tabular}

trust in technology and need for interaction on perceived ease of use is smaller than 0.05 and their regression coefficient is positive. Thus, it can be concluded that these two factors can lead to improved perceived ease of use. On the contrary, significance level of subjective norms regarding technology is larger than 0.05, implying that the relationship is not significant. Accordingly, the fourth hypothesis is confirmed if social factors include only trust in technology and need for interaction. 
Significance level of the impact of organizational factors including the availability of support, security and privacy, and features of the system and web on perceived usefulness of mobile banking is smaller than 0.05 and their regression coefficient is positive. Therefore, it can be said that these factors can improve perceived usefulness of mobile banking. Hence, the fifth hypothesis is confirmed. Similarly, significance level of the impact of organizational factors on perceived ease of use of mobile banking is smaller than 0.05 and their regression coefficient is positive.
Hence, it can be said that these factors improve perceived ease of use of mobile banking, and the sixth hypothesis is confirmed too.

Among the technological factors, significance level of the impact of perceived cost and perceived credit on perceived usefulness of mobile banking is smaller than 0.05 and their regression coefficient is positive. Thus, it can be said that perceived cost and perceived credit can improve perceived usefulness of mobile banking. However, significance level of the impact of perceived quality and availability on

Table 4. The results of the first order confirmatory factor analysis

\begin{tabular}{|c|c|c|c|c|}
\hline Variable & Questions & $\begin{array}{c}\text { Standard } \\
\text { coefficient }\end{array}$ & Critical ratio & $\begin{array}{c}\begin{array}{c}\text { Significance } \\
\text { level }\end{array} \\
\end{array}$ \\
\hline \multirow{2}{*}{$\begin{array}{l}\text { The use of } \\
\text { mobile } \\
\text { banking } \\
\text { technology }\end{array}$} & $\begin{array}{l}\text { Mobile banking application is } \\
\text { installed on my phone and I use it } \\
\text { regularly. }\end{array}$ & 0.29 & 4.607 & 0.009 \\
\hline & $\begin{array}{l}\text { I do many of my banking operations } \\
\text { through mobile banking. }\end{array}$ & 0.815 & 19.648 & $* * *$ \\
\hline \multirow{6}{*}{$\begin{array}{l}\text { Previous } \\
\text { experience of } \\
\text { using } \\
\text { technology }\end{array}$} & $\begin{array}{l}\text { I am usually interested in learning } \\
\text { and using any new technology which } \\
\text { comes to market }\end{array}$ & 0.669 & 6.208 & $* * *$ \\
\hline & $\begin{array}{l}\text { I have used new technologies such as } \\
\text { computer, Internet, etc. previously. }\end{array}$ & 0.343 & 6.256 & $* * *$ \\
\hline & $\begin{array}{l}\text { Mobile banking technology is } \\
\text { familiar for me. }\end{array}$ & 0.78 & 12.219 & $* * *$ \\
\hline & $\begin{array}{l}\text { I have the necessary information to } \\
\text { use mobile banking technology. }\end{array}$ & 0.865 & 13.07 & $* * *$ \\
\hline & $\begin{array}{l}\text { I always try to be familiar with new } \\
\text { technologies and how to use them. }\end{array}$ & 0.821 & 12.644 & $* * *$ \\
\hline & $\begin{array}{l}\text { I have no problem in using various } \\
\text { menus designed for mobile banking. }\end{array}$ & 0.821 & 12.649 & $* * *$ \\
\hline \multirow{3}{*}{$\begin{array}{l}\text { Previous } \\
\text { knowledge of } \\
\text { technology }\end{array}$} & $\begin{array}{l}\text { Using a computer is always easy and } \\
\text { simple for me. }\end{array}$ & 0.524 & 9.057 & $* * *$ \\
\hline & $\begin{array}{l}\text { I am familiar with the installation of } \\
\text { computer software. }\end{array}$ & 0.954 & 13.844 & $* * *$ \\
\hline & $\begin{array}{c}\text { Using different menus of mobile } \\
\text { banking is easy for me. }\end{array}$ & 0.738 & 11.767 & $* * *$ \\
\hline \multirow{3}{*}{$\begin{array}{l}\text { Subjective } \\
\text { norms } \\
\text { towards } \\
\text { technology }\end{array}$} & $\begin{array}{l}\text { Others encourage me to use mobile } \\
\text { banking technology. }\end{array}$ & 0.708 & 6.605 & $* * *$ \\
\hline & $\begin{array}{l}\text { Given the fact that most of my } \\
\text { colleagues and friends use mobile } \\
\text { banking, I also have to use this } \\
\text { technology. }\end{array}$ & 0.587 & 8.777 & $* * *$ \\
\hline & $\begin{array}{c}\text { Bank employees encourage } \\
\text { customers to use mobile banking. }\end{array}$ & 0.686 & 9.669 & $* * *$ \\
\hline
\end{tabular}


Continue Table 4. The results of the first order confirmatory factor analysis

\begin{tabular}{|c|c|c|c|c|}
\hline Variable & Questions & $\begin{array}{l}\text { Standard } \\
\text { coefficient }\end{array}$ & Critical ratio & $\begin{array}{c}\begin{array}{c}\text { Significance } \\
\text { level }\end{array} \\
\end{array}$ \\
\hline \multirow{4}{*}{$\begin{array}{l}\text { Trust in } \\
\text { technology }\end{array}$} & $\begin{array}{l}\text { I trust my bank in providing the } \\
\text { security of mobile banking. }\end{array}$ & 0.827 & 10.675 & $* * *$ \\
\hline & $\begin{array}{c}\text { I trust the mobile phone } \\
\text { manufacturer in producing mobile } \\
\text { phones which are proper for mobile } \\
\text { banking. }\end{array}$ & 0.726 & 9.986 & $* * *$ \\
\hline & $\begin{array}{l}\text { I trust telecommunication operators } \\
\text { in providing secure data } \\
\text { communication for doing mobile } \\
\text { banking operations. }\end{array}$ & 0.552 & 8.414 & $* * *$ \\
\hline & $\begin{array}{l}\text { The use of mobile phone for } \\
\text { banking operations will not disclose } \\
\text { my personal information. }\end{array}$ & 0.719 & 9.936 & $* * *$ \\
\hline \multirow{3}{*}{$\begin{array}{l}\text { The need for } \\
\text { interaction }\end{array}$} & $\begin{array}{l}\text { I enjoy seeing the employees who } \\
\text { work in the bank. }\end{array}$ & 0.669 & 6.208 & $* * *$ \\
\hline & $\begin{array}{l}\text { I do not care the personal attention } \\
\text { of the bank employees. }\end{array}$ & 0.001 & 0.12 & 0.99 \\
\hline & $\begin{array}{l}\text { Bank employees help me a lot doing } \\
\text { my banking operations. }\end{array}$ & 0.517 & 3.07 & 0.002 \\
\hline \multirow{3}{*}{$\begin{array}{c}\text { The } \\
\text { availability of } \\
\text { support }\end{array}$} & $\begin{array}{l}\text { When I have problems in using } \\
\text { mobile banking, bank engineers } \\
\text { guide me easily. }\end{array}$ & 0.506 & 4.616 & $* * *$ \\
\hline & $\begin{array}{l}\text { One of the benefits of mobile-based } \\
\text { banking is a lot of support by the } \\
\text { banks. }\end{array}$ & 0.663 & 13.027 & $* * *$ \\
\hline & $\begin{array}{c}\text { Bank employees and officials guide } \\
\text { me adequately to install mobile } \\
\text { banking application. }\end{array}$ & 0.544 & 10.507 & $* * *$ \\
\hline \multirow{2}{*}{$\begin{array}{l}\text { Security and } \\
\text { privacy }\end{array}$} & $\begin{array}{c}\text { The use of mobile banking is likely } \\
\text { to leak personal information. }\end{array}$ & 0.189 & 3.544 & $* * *$ \\
\hline & $\begin{array}{l}\text { Mobile banking can be used without } \\
\text { any concern about the loss of bank } \\
\text { account information. }\end{array}$ & 0.756 & 15.102 & $* * *$ \\
\hline \multirow{3}{*}{$\begin{array}{l}\text { Features of } \\
\text { the system } \\
\text { and web }\end{array}$} & $\begin{array}{l}\text { Mobile banking system has the } \\
\text { required appeal for the users. }\end{array}$ & 0.779 & 15.625 & $* * *$ \\
\hline & $\begin{array}{l}\text { Mobile banking system guides } \\
\text { customers on how to use it. }\end{array}$ & 0.388 & 7.362 & $* * *$ \\
\hline & $\begin{array}{c}\text { Mobile banking system has } \\
\text { adequate menus for doing banking } \\
\text { operations. }\end{array}$ & 0.422 & 8.024 & $* * *$ \\
\hline \multirow{2}{*}{$\begin{array}{l}\text { Perceived } \\
\text { quality }\end{array}$} & $\begin{array}{l}\text { Mobile banking offers useful and } \\
\text { satisfying services. }\end{array}$ & 0.202 & 3.779 & $* * *$ \\
\hline & $\begin{array}{l}\text { The quality of mobile banking } \\
\text { services is good. }\end{array}$ & 0.433 & 3.007 & 0.003 \\
\hline \multirow{3}{*}{ Availability } & $\begin{array}{l}\text { Mobile banking system is always } \\
\text { available. }\end{array}$ & 0.482 & 3.047 & 0.002 \\
\hline & $\begin{array}{l}\text { Disruption and problem always } \\
\text { occur in mobile banking system. }\end{array}$ & 0.401 & 2.973 & 0.003 \\
\hline & $\begin{array}{l}\text { Mobile Banking is available } \\
\text { everywhere and every time even on } \\
\text { holidays. }\end{array}$ & 0.518 & 3.071 & 0.002 \\
\hline \multirow{3}{*}{$\begin{array}{l}\text { Perceived } \\
\text { ease of use }\end{array}$} & $\begin{array}{l}\text { Learning to use mobile banking is } \\
\text { easy. }\end{array}$ & 0.405 & 2.978 & 0.003 \\
\hline & $\begin{array}{l}\text { I think it is difficult to use mobile } \\
\text { banking. }\end{array}$ & 0.773 & 7.281 & $* * *$ \\
\hline & $\begin{array}{l}\text { I think it is easy for me to use } \\
\text { mobile banking skillfully. }\end{array}$ & 0.237 & 4.891 & $* * *$ \\
\hline
\end{tabular}


Continue Table 4. The results of the first order confirmatory factor analysis

\begin{tabular}{|c|c|c|c|c|}
\hline Variable & Questions & $\begin{array}{c}\text { Standard } \\
\text { coefficient }\end{array}$ & Critical ratio & $\begin{array}{c}\text { Significance } \\
\text { level }\end{array}$ \\
\hline \multirow{4}{*}{ Perceived risk } & $\begin{array}{l}\text { I think it will be safe to do my } \\
\text { banking operations through mobile } \\
\text { banking. }\end{array}$ & 0.503 & 10.424 & $* * *$ \\
\hline & $\begin{array}{l}\text { I think mobile banking can run my } \\
\text { banking operations precisely. }\end{array}$ & 0.552 & 8.414 & $* * *$ \\
\hline & $\begin{array}{l}\text { I think it is correct to do banking } \\
\text { processes through mobile banking. }\end{array}$ & 0.686 & 9.669 & $* * *$ \\
\hline & $\begin{array}{l}\text { I think if I use mobile banking, I will } \\
\text { reduce the risk of errors. }\end{array}$ & 0.827 & 10.675 & $* * *$ \\
\hline \multirow{3}{*}{ Perceived cost } & $\begin{array}{l}\text { The use of mobile banking has a high } \\
\text { cost. }\end{array}$ & 0.815 & 19.648 & $* * *$ \\
\hline & $\begin{array}{l}\text { I think that the cost of Internet access } \\
\text { for the use of mobile banking } \\
\text { services is high. }\end{array}$ & 0.827 & 10.675 & $* * *$ \\
\hline & $\begin{array}{l}\text { I face some financial barriers (such as } \\
\text { the cost of Internet access) to use } \\
\text { mobile banking. }\end{array}$ & 0.257 & 2.687 & 0.007 \\
\hline \multirow{2}{*}{$\begin{array}{l}\text { Perceived } \\
\text { credit }\end{array}$} & $\begin{array}{c}\text { In requesting and receiving } \\
\text { information such as bank statements, } \\
\text { a high security is granted to mobile } \\
\text { banking. }\end{array}$ & 0.352 & 2.907 & 0.004 \\
\hline & $\begin{array}{l}\text { In my information interactions with } \\
\text { bank through mobile phone, a high } \\
\text { security is granted to mobile banking. }\end{array}$ & 0.491 & 3.054 & 0.002 \\
\hline \multirow{3}{*}{$\begin{array}{l}\text { Intention to } \\
\text { use } \\
\text { technology }\end{array}$} & $\begin{array}{l}\text { I try to do my banking operations via } \\
\text { mobile phone. }\end{array}$ & 0.503 & 3.061 & 0.002 \\
\hline & $\begin{array}{l}\text { I am aware of the benefits of mobile } \\
\text { banking as much as possible. }\end{array}$ & 0.579 & 3.102 & 0.002 \\
\hline & $\begin{array}{l}\text { If I have a mobile phone with Internet } \\
\text { access, I will use mobile banking } \\
\text { services. }\end{array}$ & 0.642 & 12.004 & $* * *$ \\
\hline \multirow{3}{*}{$\begin{array}{l}\text { Perceived } \\
\text { usefulness }\end{array}$} & $\begin{array}{l}\text { Mobile banking is useful for doing } \\
\text { banking operations. }\end{array}$ & 0.829 & 14.661 & $* * *$ \\
\hline & $\begin{array}{l}\text { I think the use of mobile banking } \\
\text { improves my banking operations. }\end{array}$ & 0.29 & 4.607 & 0.009 \\
\hline & $\begin{array}{c}\text { Mobile banking leads to the } \\
\text { facilitation of my banking operations. }\end{array}$ & 0.873 & 28.404 & $* * *$ \\
\hline \multirow{3}{*}{$\begin{array}{l}\text { Perceived } \\
\text { ease of use }\end{array}$} & $\begin{array}{l}\text { I think it is difficult to use mobile } \\
\text { banking. }\end{array}$ & 0.471 & 10.033 & $* * *$ \\
\hline & $\begin{array}{l}\text { I think it is easy for me to use mobile } \\
\text { banking skillfully. }\end{array}$ & 0.388 & 7.362 & $* * *$ \\
\hline & $\begin{array}{l}\text { It is easy to learn to use mobile } \\
\text { banking. }\end{array}$ & 0.815 & 19.648 & $* * *$ \\
\hline \multirow{4}{*}{$\begin{array}{l}\text { Attitude } \\
\text { towards using } \\
\text { technology }\end{array}$} & $\begin{array}{l}\text { Mobile banking technology is a } \\
\text { necessity of banking. }\end{array}$ & 0.773 & 7.281 & $* * *$ \\
\hline & $\begin{array}{l}\text { I agree with mobile banking } \\
\text { technology in doing banking } \\
\text { operations. }\end{array}$ & 0.837 & 17.001 & $* * *$ \\
\hline & $\begin{array}{l}\text { The future of banking will be difficult } \\
\text { without mobile banking technology. }\end{array}$ & 0.707 & 14.317 & $* * *$ \\
\hline & $\begin{array}{l}\text { If customers use mobile banking, } \\
\text { they will save their time and money. }\end{array}$ & 0.277 & 5.116 & $* * *$ \\
\hline
\end{tabular}

\footnotetext{
*** is significant at the level of 0.001
} 


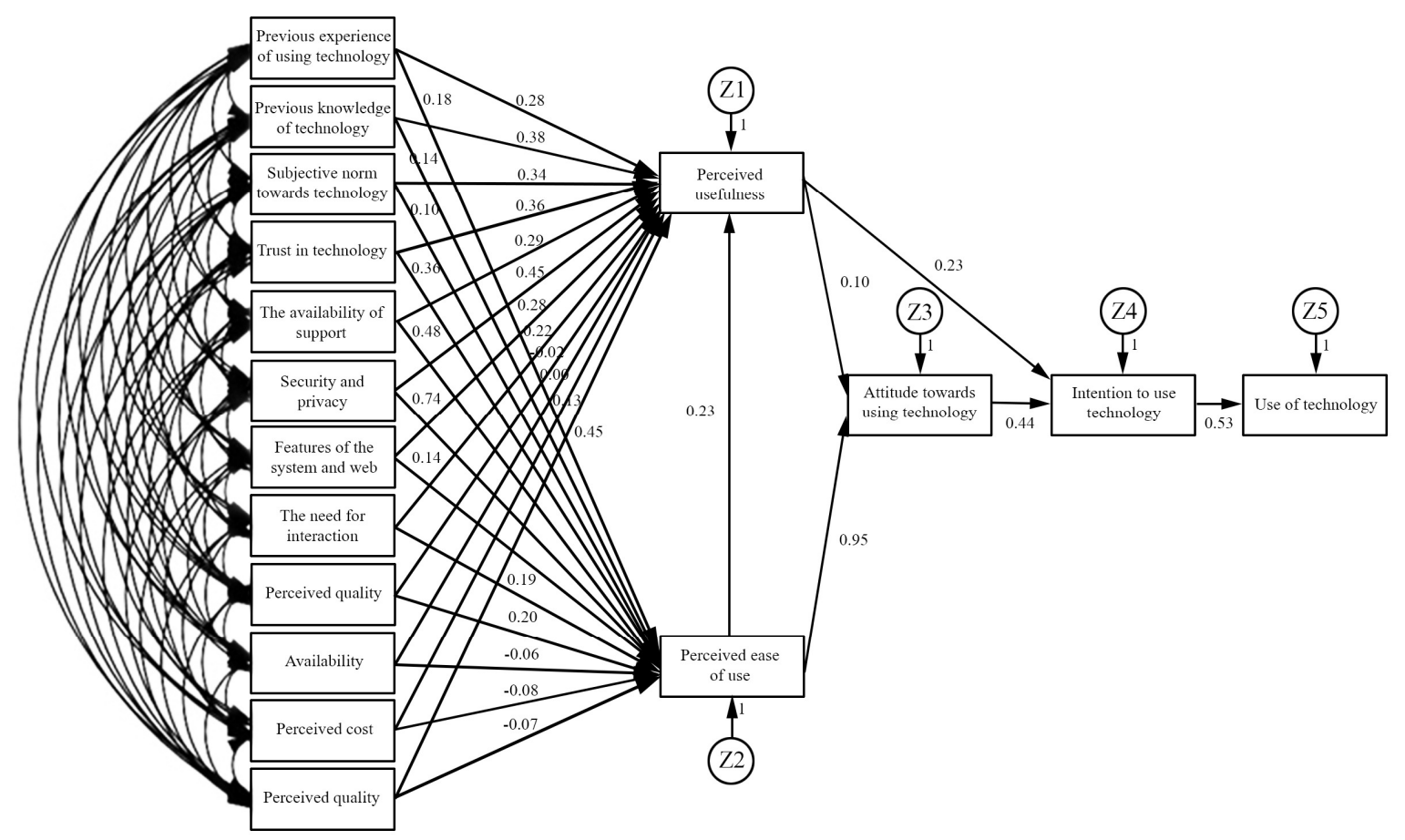

Figure 2. Testing the model based on path analysis method

perceived usefulness of mobile banking is larger than 0.05, implying that these relationships are not significant. Accordingly, the seventh hypothesis is confirmed if technological factors include only perceived costs and perceived credit. Moreover, among the technological factors, significance level of the impact of perceived quality on perceived ease of use is smaller than 0.05 and its regression coefficient is positive. Hence, it can be said that perceived quality can lead to improved perceived ease of use. In contrast, significance level of the impact of availability, perceived costs, and perceived credit on perceived ease of use is larger than 0.05 , implying that this relationship is not significant. Accordingly, the eighth hypothesis is confirmed if technological factors include only perceived quality.

Significance level of the impact of perceived usefulness on attitude towards the use of mobile banking is smaller than 0.05 and its regression coefficient is positive.
Thus, it can be said that perceived usefulness can lead to the improved attitude towards the use of mobile banking. In this regard, the ninth hypothesis is confirmed. Likewise, significance level of the impact of perceived ease of use on attitude towards the use of mobile banking is smaller than 0.05 and its regression coefficient is positive. Therefore, it can be said that perceived ease of use of mobile banking can lead to improved attitude towards the use of mobile banking. Accordingly, the tenth hypothesis is confirmed. Significance level of the impact of attitude towards the use of mobile banking on intention to use mobile banking is smaller than 0.05 and its regression coefficient is positive. Therefore, it can be said that attitude towards the use of mobile banking can lead to improved intention to use mobile banking. Hence, the eleventh hypothesis is confirmed. Finally, significance level of the impact of intention to use mobile banking on the use of mobile banking is smaller than 
0.05 and its regression coefficient is positive. Thus, it can be said that intention to use mobile banking can improve the use of mobile banking. Accordingly, the twelfth hypothesis is confirmed too.

In order to ensure the obtained results, fit indices of the model should be examined so that the obtained results can be generalized/extended to all companies. Based on structural equation modeling, the main indices of structural model can be divided into three general categories of absolute, relative, and thrifty each of which use other sub- indices. The values of the main and sub-indices of fit for the research model are shown in table 6 .

The results of the table 6 specify that among the absolute indices, GFI is in an acceptable range. All relative indices of TLI, NFI, and CFI are also in the acceptable range. Similarly, the values obtained for thrifty indices such as PNFI, PCFI, RMSER, and CMIN/DF are acceptable. Thus, most used indices indicate the fit of the research model and the results of the estimating the relationships of the research model are valid.

\section{CONCLUSIONS}

In order to increase the possibility of using mobile banking by citizens, considering effective factors and developing and implementing appropriate policies by banks seem to be necessary and inevitable. Given the decisive role of external factors in

Table 5. The results of testing the research hypotheses

\begin{tabular}{|c|c|c|c|c|c|}
\hline Independent variable & $\begin{array}{c}\text { Dependent } \\
\text { variable }\end{array}$ & $\begin{array}{l}\text { Standard } \\
\text { coefficient }\end{array}$ & $\begin{array}{c}\text { Standard } \\
\text { error }\end{array}$ & $\begin{array}{c}\text { Critical } \\
\text { ratio }\end{array}$ & $\begin{array}{c}\begin{array}{c}\text { Significance } \\
\text { level }\end{array} \\
\end{array}$ \\
\hline $\begin{array}{c}\text { Previous experience of using } \\
\text { mobile banking }\end{array}$ & \multirow{12}{*}{$\begin{array}{l}\text { Perceived } \\
\text { usefulness }\end{array}$} & 0.275 & 0.064 & 4.207 & 0.000 \\
\hline $\begin{array}{c}\text { Previous knowledge of using } \\
\text { mobile banking }\end{array}$ & & 0.375 & 0.056 & 5.683 & 0.000 \\
\hline $\begin{array}{c}\text { Subjective norm towards the } \\
\text { use of mobile banking }\end{array}$ & & 0.335 & 0.055 & 5.644 & 0.000 \\
\hline $\begin{array}{l}\text { Trust in the use of mobile } \\
\text { banking }\end{array}$ & & 0.358 & 0.061 & 6.384 & 0.000 \\
\hline $\begin{array}{c}\text { Need for interaction in mobile } \\
\text { banking }\end{array}$ & & 0.29 & 0.052 & 5.09 & 0.000 \\
\hline $\begin{array}{c}\text { The availability of mobile } \\
\text { banking support }\end{array}$ & & 0.453 & 0.057 & 7.832 & 0.000 \\
\hline $\begin{array}{c}\text { Security and privacy of mobile } \\
\text { banking }\end{array}$ & & 0.282 & 0.063 & 6.161 & 0.000 \\
\hline $\begin{array}{c}\text { The features of mobile banking } \\
\text { system }\end{array}$ & & 0.216 & 0.064 & 4.897 & 0.000 \\
\hline $\begin{array}{c}\text { Perceived quality of mobile } \\
\text { banking }\end{array}$ & & 0.023 & 0.067 & -0.408 & 0.684 \\
\hline $\begin{array}{l}\text { The availability of mobile } \\
\text { banking }\end{array}$ & & 0.003 & 0.071 & 0.051 & 0.959 \\
\hline $\begin{array}{c}\text { Perceived cost of mobile } \\
\text { banking }\end{array}$ & & 0.117 & 0.041 & 2.409 & 0.016 \\
\hline $\begin{array}{c}\text { Perceived credit of mobile } \\
\text { banking }\end{array}$ & & 0.448 & 0.059 & 7.76 & 0.000 \\
\hline $\begin{array}{c}\text { Previous experience of using } \\
\text { mobile banking }\end{array}$ & & 0.183 & 0.053 & 3.166 & 0.002 \\
\hline $\begin{array}{c}\text { Previous knowledge of using } \\
\text { mobile banking }\end{array}$ & & 0.142 & 0.051 & 2.386 & 0.017 \\
\hline $\begin{array}{l}\text { Subjective norm towards the } \\
\text { use of mobile banking }\end{array}$ & & 0.103 & 0.05 & 1.937 & 0.053 \\
\hline
\end{tabular}


Continue Table 5. The results of testing the research hypotheses

\begin{tabular}{|c|c|c|c|c|c|}
\hline Independent variable & $\begin{array}{c}\text { Dependent } \\
\text { variable }\end{array}$ & $\begin{array}{c}\text { Standard } \\
\text { coefficient }\end{array}$ & $\begin{array}{c}\text { Standard } \\
\text { error }\end{array}$ & $\begin{array}{c}\text { Critical } \\
\text { ratio }\end{array}$ & $\begin{array}{c}\text { Significance } \\
\text { level }\end{array}$ \\
\hline Trust in mobile banking & \multirow{9}{*}{$\begin{array}{l}\text { Perceived ease } \\
\text { of use }\end{array}$} & 0.357 & 0.052 & 7.564 & 0.000 \\
\hline $\begin{array}{l}\text { Need for interaction in mobile } \\
\text { banking }\end{array}$ & & 0.481 & 0.042 & 10.653 & 0.000 \\
\hline $\begin{array}{c}\text { The availability of mobile } \\
\text { banking support }\end{array}$ & & 0.744 & 0.037 & 20.423 & 0.000 \\
\hline $\begin{array}{c}\text { Security and privacy of mobile } \\
\text { banking }\end{array}$ & & 0.143 & 0.058 & 3.512 & 0.000 \\
\hline $\begin{array}{c}\text { The features of mobile banking } \\
\text { system }\end{array}$ & & 0.194 & 0.057 & 5.037 & 0.000 \\
\hline $\begin{array}{c}\text { Perceived quality of mobile } \\
\text { banking }\end{array}$ & & 0.195 & 0.061 & 3.874 & 0.000 \\
\hline $\begin{array}{l}\text { The availability of mobile } \\
\text { banking }\end{array}$ & & -0.064 & 0.066 & -1.198 & 0.231 \\
\hline $\begin{array}{l}\text { Perceived cost of mobile } \\
\text { banking }\end{array}$ & & -0.079 & 0.038 & -1.813 & 0.07 \\
\hline $\begin{array}{c}\text { Perceived credit of mobile } \\
\text { banking }\end{array}$ & & -0.073 & 0.055 & -1.404 & 0.16 \\
\hline $\begin{array}{l}\text { Perceived usefulness of mobile } \\
\text { banking }\end{array}$ & \multirow{2}{*}{$\begin{array}{c}\text { Attitude } \\
\text { towards the } \\
\text { use of } \\
\text { technology }\end{array}$} & 0.103 & 0.041 & 2.288 & 0.022 \\
\hline $\begin{array}{c}\text { Perceived ease of use of mobile } \\
\text { banking }\end{array}$ & & 0.95 & 0.079 & 10.738 & 0.000 \\
\hline $\begin{array}{c}\text { Attitude towards the use of } \\
\text { mobile banking }\end{array}$ & $\begin{array}{l}\text { Intention to } \\
\text { use mobile } \\
\text { banking }\end{array}$ & 0.435 & 0.052 & 8.362 & 0.000 \\
\hline Intention to use mobile banking & $\begin{array}{l}\text { The use of } \\
\text { mobile } \\
\text { banking }\end{array}$ & 0.529 & 0.066 & 11.533 & 0.000 \\
\hline
\end{tabular}

the use of mobile banking, this research investigated the importance of each of these factors based on the opinions of the sample members and presented an appropriate model. According to the results of the research, personal factors including previous experience and previous knowledge of mobile banking have a positive role in using this technology. One of the most important problems in the acceptance and use of new systems and technologies is the lack of knowledge in using such technologies. Many people may be willing to use such systems, but they do not know how to use them. Experience and previous knowledge have an obvious effect on both perceived ease of use and perceived usefulness of mobile banking. Hence, the role of these factors on the adoption of this technology is approved. Kim et al. (2010) investigated the factors affecting the adoption of payments through mobile phones and found similar results. Riquelme and Rios (2010) also found that previous experience and previous knowledge of mobile banking would help the adoption of mobile banking technology. Moreover, other results of the research showed that the social factors of subjective norms regarding technology, trust in technology, and the need for interaction influence perceived usefulness of mobile banking, and trust in technology and the need for interaction have impact on perceived ease of use of technology. Basically, in the adoption of a new technology people are more concerned with the issue that whether or not they can delegate their work to that technology. Additionally, some people are reluctant to use mobile banking because of some specific reasons. These reasons include the need to 
employee assistance for doing banking operations, enjoying personal interaction, and the importance of personal attention of people, the first one of which was identified as the most influential factor. Similar results were obtained by other researchers such as Gilani Nia and Mousavian (2009), Moghali (2007), Hashemian \& Isaei (2014), and Kim et al. (2009). In addition, Humner and AlQahtani (2009) believe that the availability of support stimulates users and leads them to use technology. These results are in line with the findings of other researchers such as Konjkav Monfared \& Mirhossein (2014), Hashemian \& Isaei (2014), Davis (1989) and Wang et al. (2008). Finally, among the technological factors, the impact of perceived costs and perceived credit on perceived usefulness of mobile banking and the impact of perceived quality on perceived ease of use were confirmed.

The results of the research show that personal factors such as previous experience and previous knowledge of mobile banking have a significant positive impact on perceived ease of use and perceived usefulness of mobile banking. Social factors including subjective norms, trust in technology and the need for interaction had a significant positive impact on perceived ease of use and perceived usefulness of mobile banking. However, only the positive impact of trust in technology and the need for interaction on perceived ease of use was significant. Organizational factors including the availability of support, security and privacy, and the features of the system and web had a significant positive impact on perceived ease of use and perceived usefulness of mobile banking. Among technological factors, only perceived costs and perceived credit had a significant positive impact on perceived usefulness of mobile banking. Moreover, only the positive impact of perceived quality on perceived ease of use of mobile banking was confirmed. Perceived usefulness and perceived ease of use had a positive effect on attitude toward mobile banking. In addition, the positive impact of attitude towards the use of mobile banking on the intention to use mobile banking and the impact of this latter on the use of mobile banking was confirmed.

According to the obtained results, bank managers are recommended to use mass media, especially television advertising, radio, newspapers and various magazines to introduce the features and advantages resulting from the use of mobile banking and, hence, increase the awareness of customers about this technology. Additionally, trial versions of mobile banking can provide

\section{Table 6. Fit indices of the research model}

\begin{tabular}{|c|c|c|c|}
\hline The type of fit index & Index & Acceptable range & Main model \\
\hline \multirow{6}{*}{ Absolute } & NPAR & - & 143 \\
\hline & DF & - & 10 \\
\hline & $\mathrm{P}$ & $>0.05$ & 0.051 \\
\hline & CMIN (Chi Square) & - & 26.589 \\
\hline & AGFI & $>0.9$ & 0.740 \\
\hline & GFI & $>0.9$ & 0.981 \\
\hline \multirow{3}{*}{ Relative } & TLI & $>0.9$ & 0.90 \\
\hline & NFI & $>0.9$ & 0.989 \\
\hline & CFI & $>0.9$ & 0.991 \\
\hline \multirow{4}{*}{ Thrifty } & PNFI & $>0.5$ & 0.580 \\
\hline & PCFI & $>0.5$ & 0.580 \\
\hline & RMSEA & $<0.08$ & 0.014 \\
\hline & CMIN/DF & $<0.5$ & 2.658 \\
\hline
\end{tabular}


customers with new experiences about this technology. A massive effort to make people believe that mobile banking is superior than other means of e-banking and creating this tendency among target customers to use mobile banking are among other proposed recommendations. Given the impact of security on the use of mobile banking, through informing customers of security issues and the standards observed by the bank to increase their awareness and providing financial insurance against any Internet misuse and possible errors in the payment or receipt of funds, manager can make customers use mobile banking as they feel more secure. Reduced downtime in mobile banking tools, increased transactional quality and the storage of transactions in databases, the development of hardware, software, technical, legal, cultural and security infrastructures, and the design of easy and more attractive applications, can lead to the expanded use of mobile banking as they improve the support of mobile banking system and services. In addition, banks' marketing managers are recommended to provide mobile banking technology with various advantages such as low cost, validity and reliability, and having better quality compared with the other means of e-banking, so that they can encourage customers to use this technology. Using measures such as the simplification of the design of applications, easy access, and getting the viewpoints of customers to make mobile banking more user-friendly, banks should take steps to improve the perceived ease of use of mobile banking. Furthermore, the possibility to offer most services of e-banking system through mobile banking and increase the speed of transactions can improve the usefulness perceived by customers and, thus, their tendency to use mobile banking.
It is recommended that future researchers test the model of this research as comparative study between public and private banks in order to compare the viewpoint of customers about hardware and software structures of these two main sections of banking industry. In addition, researchers are suggested to investigate the model of this research for other new technologies, especially e-banking tools. Finally, it is recommended that future researchers, by adopting a macro perspective, consider variables such as macroeconomic indicators, cultural and political conditions and evaluate the effects they may have on the intention of customers to use mobile banking.

The main limitation of this was the collection of data by using a related questionnaire. Some bank employees did not show the necessary cooperation in responding the questions of the questionnaire. Owing to the lake of face-toface, by phone and even Internet communication channels, the questionnaire was not distributed among some other employees. Another limitation was related to having access to some databases in order to identify the factors influencing the adoption of mobile banking technology and access to a standard questionnaire. According to this limitation, some factors influencing the adoption of mobile banking technology were eliminated from the process of the research.

\section{References}

Abdi, B., \& Danaeifar, H. (2010). EGovernment Adoption in Iran: The Role of Demographic, Social and Organizational Factors in Technology Adoption. Journal of public management perspective, 1 (1), 41-67 (in Persian)

Agarwal, R., \& Karahanna. (2000). E. 


\title{
ХИБРИДНИ МОДЕЛ ФАКТОРА КОЈИ УТИЧУ НА УСВАЈАҢЕ МОБИЛНИХ БАНКАРСКИХ ТЕХНОЛОГИЈА КОД КЛИЈЕНАТА ИРАНСКИХ БАНАКА
}

\author{
Bagher Asgarnezhad Nouri, Milad Soltani
}

\section{Извод}

Ова студија има за циљ креирање хибридног модела за усвајање мобилног банкарства у банкарској индустрији Ирана. На основу разматраних модела усвајања технологија, главни ефективни фактори су подељени у четири опште категорије, укључујући личне, друштвене, организационе и технолошке факторе. Популација посматрана у овој студији састојала се од клијената државних банака. Обзиром на величину популације, на основу Морганове табеле, изабрано је 384 клијента као узорак у студији. Стандардни упитник коришћен је за прикупљање потребних података за све варијабле истраживања. Хипотезе истраживања су тестиране коришћењем модела структуралних једначина уз помоћ софтвера "AMOS". Резултати показују да неки лични, друштвени, организациони и технолошки фактори имају позитиван значајан ефекат на перцепцију корисности и перципирану лакоћу коришћења мобилног банкарства. Утврђена корисност и перцепција једноставне употребе имају позитиван значајан утицај на став према мобилном банкарству. Поред тога, потврђен је и значајан позитиван ефекат односа према употреби мобилног банкарства на тенденцију коришћтења мобилног банкарства и обрнуто.

Кључне речи: мобилно банкарство, модели прилагођавања технологија, лични фактори, друштвени фактори, технолошки фактори, организациони фактори, опажена корисност, перцепција једноставне употребе

Time flies when you're having fun: Cognitive absorption and beliefs about information technology usage. MIS Quarterly, 24 (4), 665- 694.

Ajzen, I. (1989). Attitude, structure, and behavior. pp. 241-274. in A. R. Pratkanis, S. J.Breckler, A. G. Greenwald (Eds.), Attitude Structure and Function, Hillsdale, NJ: Lawrence Erlbaum Associates.

Amin, H., Baba, R., \& Muhammad, M.Z. (2006). An analysis of mobile banking acceptance by Malaysian customers. Sunway Academic Journal, 4, 1-12.

Anderson, J. (2010). M-banking in developing markets: competitive and regulatory implication. Info, 12 (1), 18-25.
Ashtiani, P.G., \& Asadi, F. (2011). The effect in overcoming the resistance of consumers to mobile banking adoption of Melli bank of Iran, in Ninth International Conference on Management, Sharif University of Technology: Tehran, 2011. (in Persian).

Bandura, A. (2001). Social cognitive theory: An Agentic perspective. Annual review of psychology, 52 (1), 1- 26.

Bastic, M., \& Gojcic, S. (2012). Measurement scale for eco-component of hotel service quality. International Journal of Hospitality Management, 31 (3), 1012-1020.

Behboudi, M., Abedini, A., \& Jalilvand, M. (2013). Adoption of mobile banking by 
Iranian bank customers. Journal of Marketing Management, 8 (18), 21-46. (in Persian)

Bhattacherjee, A. (2002). Individual trust in online firms: Scale development and initial test. Journal of Management Information Systems, 19 (1), 211-241.

Bonham, G., Seifert, J., \& Thorson, S. (2001), The Transformational Potential of EGovernment: The Role of Political Leadership. Paper Presented at 4th Pan European International Relations Conference, Canterbury, September 6-10, 2001. 1-9. University of Kent.

Chen, L., Gillenson, M., \& Sherrell, D. (2004). Consumer acceptance of virtual stores: A theoretical model and critical success factors for virtual stores. ACM SIGMIS Database, 35 (2), 8-31.

Chiu, Y.B., Lin, C.P., \& Tang, L.L. (2005). Gender differs: Assessing a model of online purchase intentions in e-tail service. International Journal of Service Industry Management, 16 (5), 416-435.

Das, T.D., \& Teng, B. Sh. (2001). Trust, control, and risk in strategic alliance: an integrated framework. Organization Studies, 12 (4), 251-283.

Davis, F., Bagozzi, R. \& Warshaw, P. (1992). Extrinsic and intrinsic motivation to use computers in the workplace. Journal of Applied Social Psychology, 22(14), 11111132.

Davis, F.D. (1986). A technology acceptance model for empirically testing new end-user information systems: Theory and results. Unpublished doctoral dissertation, Sloan School of Management, MIT, Cambridge, MA.

Davis, F.D. (1989). Perceived usefulness, perceived ease of use, and user acceptance of information technology. MIS Quarterly, 13 (3), 319-341.
Dickerson, S.S. (2003). Gender differences in stories of everyday Internet use. Health Care for Women International, 24 (5), 434-451.

Donnelley, T. Jr. (2004). Extending the technology acceptance model: Additional factors affecting the adoption of e-commerce by senior American residents. Doctoral dissertation, Nova Southeastern University, Florida.

Elahi, S., Ghanbari, M.H., \& Shayan, A. (2012). Determining the effective factors in adoption of mobile banking technology by customers. Journal of Commercial Law, 52, 211-247. (in Persian)

Erdem, T., \& Swait, J. (2004). Brand credibility brand consideration and choice. Journal of Consumer Research, 31, 191-198.

Fatemi-e-ardekani, V. (2005). E-banking and its impact on banks' administrative processes: the case of Internet bank, The researches of the Third National Conference on E-commerce, Tehran: Planning department of Economic Affairs of the Ministry of Commerce.Iran. (in Persian)

Ghilani Nia, S., \& Mousavian, S.J. (2009). Identification of effective factors on customer orientation in using electronic banking services. Productivity Management, 3 (11), 103-133. (in Persian)

Gholipouri Soleimani, A., \& Imani, S. (2010). The route of technology in banking. Management Journal, 159, 22-25. (in Persian)

Ghorbani Zadeh, V., Hasan Nanghir, S.T., \& Roodsaz, H. (2013). Meta-analysis of effective factors on the adoption of information technology in Iran, Management researches in Iran, 17 (2), 177-196. (in Persian)

Hamner, M., \& Al-Qahtani, F. (2009). Enhancing the case for electronic government in developing nations: A people- 
centric study focused in Saudi Arabia. 311.

Government Information Quarterly, 26, Knight, M.B., \& Pearson, J.M. (2005). 137-143.

The changing demographics: The

Hashemian, M., \& Isaei, M.T. (2014). Investigating and identifying critical factors in customer acceptance along with the bank. New Marketing Research, 1 (3), 99-108. (in Persian)

Hassanzadeh, A., \& Pourfard, F. (2003). Electronic banking, Quarterly Journal of Economics, 101, 10-14. (in Persian)

Humner, M., \& Ghazi, R. (2009). Expanding the Technology Acceptance Model to Examine Personal Computing Technology Utilization in Government Agencies in Developing Countries. Government Information Quarterly, 26 (1), 128-136.

Hung, S., Chang, C., \& Yu, T. (2006). Determinants of user acceptance of the egovernment services: The case of online tax filing and payment system. Government Information Quarerlyt, 23 (1), 97- 122.

Kamal, M.M. (2006). IT innovation adoption in the government sector: identifying the critical success factors. Journal of Enterprise Information Management, 19 (2), 192-222.

Karkhaneh, S., \& Mohammadi, S. (2012). Offering a model for the adoption of mobile banking from the viewpoint of customers and comparing it with the world's famous models. Journal of Marketing Management, 7(16). 109-132. (in Persian)

Kim, C., Mirusmonov, M., \& Lee, I. (2010). An empirical examination of factors influencing the intention to use mobile payment. Computers in Human Behavior, 26 (3), 310-322.

Kim, G., Shin, B., \& Lee, H.G. (2009). Understanding dynamics between initial trust and usage intentions of mobile banking. Information Systems Journal, 19 (3), 283diminishing role of age and gender in computer usage. Journal of Organizational and End User Computing, 17 (40), 49-65.

Koenig-Lewis, N., Palmer, A., \& Moll, A. (2010). Predicting young consumers' take up of mobile banking services. International Journal of Bank Marketing, 28 (5), 410-432.

Konjkav Monfared, A.R., \& Mirhoseini, M. (2014). Factors affecting the adoption of mobile banking customers bank branches export city of Yazd. Journal of Marketing Management, 2 (3), 107-120. (in Persian)

Konjkav-e-monfared, A.R., \& Mirhosseini, M. (2013). Explaining the Affecting Factors of M-Banking Acceptance by Saderat Bank's Customers. Journal of Marketing Management, 8 (18), 107-120. (in Persian)

Laukkanen, T. (2007). Internet vs mobile banking: comparing customer value perceptions. Business Process Management Journal, 13 (6), 788-797.

Lee, J., \& Rao, H.R. (2007). Percieved risks, counter-beliefs and intention to use anti-counter-terrorism websites: an exploratory study of government-citizens online interactions in a turbulent environment. Decision Support Systems, 43 (4), 1431-49.

Lee, K.C. \& Chung, N. (2009). Understanding factors affecting trust in and satisfaction with mobile banking in Korea: A modified DeLone and McLean's model perspective. Interacting with Computers, 21 (5/6), 385-392.

Lovelock, C., Patterson, P., \& Walker, R. (2001). Services Marketing: An Asia-Pacific Perspective, 2nd ed., Englewood Cliffs, NJ: Prentice-Hall

Maleki, M., \& Akbari, P. (2010). 
Investigating the role of electronic banking in Iran. Bank and Economics, 112, 14-20. (in Persian)

Mathieson, K. (1991). Predicting User Intentions: Comparing the Technology Acceptance Model with the Theory of Planned Behavior. Information Systems Research, 2(3), 173-19

Mattila, M., Karjaluoto, H., \& Pento, T. (2003). Internet banking adoption among mature customers: Early ma-jority or laggards? Journal of Services Marketing, 17(5), 514-528.

Moghadasi, A. (2010). A Variety of Payment Methods in E-banking. Monthly Magazine of Information Technology Age, 58, 75-71. (in Persian)

Moghli, A.S. (2007). Adoption of ebanking among Shiraz bank's customers, Journal of Management Science of Iran, 2 (7), 81-98. (in Persian)

Piralidehi, F., Alibeigi, A.H., \& Mohammadi, S. (2013). IPM technology adoption among orchardists of Dalahoo city. Journal of Agricultural Extension and Education, 6 (4), 107-123. (in Persian)

Ramayah, T., \& Lo, M.C. (2007), Impact of shared beliefs on "perceived usefulness" and ease of use" in the implementation of an enterprise resource planning system. Management Research News, 30 (6), 420431.

Rezaei, H., Khazaei, J., \& Shabani, J. (2012). Investigating the tendency to electronic purchasing based on the development of the technology acceptance model. New Marketing Research, 2 (1), 93110. (in Persian)

Riquelme, H., \& Rios, R. (2010). The moderating effect of gender in the adoption of mobile-banking. International Journal of bank marketing, 28 (5), 328-341.

Rogers, E.M. (1995). Diffusion of
Innovations. 4th ed., New York: The Free Press.

Saleh Ahmadi, Z., Karimzadegan Moghadam, D., \& Amirkhani, A.H. (2011). Technology acceptance models and their application in technology transfer, The First Conference on Smart Computer Systems and their Applications, Payame Noor University, Tehran. (in Persian)

Salehi, S. \& Rezaeimoghadam, K. (2009). Attitude and willingness to use tillage variable technology. Iranian Journal of Agricultural Science, 40 (1), 64-51. (in Persian)

Sarfarazi, M. (2009). Interrelationship between mobile banking and mobile business. Electronic Banking and Insurance Magazine, 51. (in Persian)

Schneider, G. (2006). Business strategies. Andy Pickering, Boston. Thomson Course Technology.

Selwyn, N., Gorard, S., Furlong, J. \& Madden, A. (2003). Older adults' use of information and communications technology in everyday life. Ageing and Society, 23 (5), 561-583.

Szajna, B. (1996). Empirical evaluation of the revised technology acceptance model. Management Science, 42 (1), 85-92.

Taghavifard, M.T., \& Torabi, M. (2010). Factors affecting the use of mobile banking services by customers and rank them Case study: Tejarat Bank branches in Tehran. Journal of Business Management Researches, 2 (3), 136-162. (in Persian).

Tan, M. \& Teo, T.S.H. (2000). Factors influencing the adoption of Internet banking. Journal of the AIS, 1 (1).

Tanner, J.C. (2008). Consumers still wary of m-commerce. Telecom Asia, 19 (7), 8-19.

Teo, T. (2010). A path analysis of preservice teachers' attitudes to computer use: applying and extending the technology 
acceptance model in an educational context. Interactive Learning Environments, 18 (1), 65-79.

Titova, Y., \& Girard, A. (2014). The impact of trading and hedging derivatives on banking efficiency in Eurozone. World Finance Conference, July 2-4, 2014. Venice, Italy.

Vafaei, N. (2010). Identification and Prioritization of the Factors Affecting the Adoption of Mobile Banking from the Viewpoint of Customers (The case of Melli Banks Branches in Iran, Tehran). Master Thesis of Business Administration, Tarbiat Modarres University. (in Persian)

Venkatesh, V., \& Davis, F.D. (2000). A theoretical extension of the technology acceptance model: Four longitudinal field studies. Management Science, 46 (2), 186204.

Venus, D. \& Safayan, M. (2002). Methods of Banking Services Marketing for Iranian Banks. Tehran: Negahe Danesh Publiction. (in Persian)

Wang, C., Lo, S., \& Fang, W. (2008). Extending the technology acceptance model to mobile telecommunication innovation: the existence of network externalities. Journal of Consumer Behavior, 7 (2), 101-110.

Wessels, L., \& Drennan, J. (2010). An investigation of consumer acceptance of Mbanking. International Journal of Bank Marketing, 28 (7), 547-568.

Wu, J., Wang, S., \& Lin, L. (2007). Mobile computing acceptance factors in the healthcare industry: a structural equation model. International Journal of Medical Informatics, 76, 66-77.

Zhou, T., Lu, Y., \& Wang, B. (2010). Integrating TTF and UTAUT to explain mobile anking user adoption. Computers in Human Behavior, 26 (4), 760-767. 